\title{
Public Support for Small and Medium-Sized Business in the Regions of the Russian Federation
}

\author{
${ }^{1}$ Ekaterina A. Eremeeva, ${ }^{2}$ Natalya V. Volkova, ${ }^{3}$ Alina M. Khamidulina \\ ${ }^{1,2,3}$ Kazan Federal University, Institute of Management, Economics and Finance, Kazan, 420008, Russia
}

Received: 15th December 2017, Accepted: 20th December 2017, Published: 31st December 2017

\begin{abstract}
The article considers the measures of State support of small and medium entrepreneurship (SME) in particular regions of the Russian Federation. For reference we selected the Republic of Tatarstan, Amur oblast, Kamchatka Krai. Examination of these regions make it possible to compare the development of small and middle-sized business entities in different geographic regions and administrative districts of Russia. Development of small and medium-sized business (SMB) currently seems relevant for Russian regions. Small and mediumsized business put significant contribution into the regional economics, gross territorial product and the budget of the region. Those entities provide advanced competitive environment and improve the quality of goods and services. Besides, small and middle-sized business increases the number of jobs created and partially address the issue of unemployment. In this regard studying the experience of different regions of the Russian Federation in creating favorable conditions and support for small and medium-sized entrepreneurship seem appropriate. The impact of state support measures for SME is also analyzed in the article. This analysis is based on the comparison of the state support measures for SME under implementation and the level of small and mediumsized businesses development in the regions covered. The analysis resulted in the conclusion about key results and perspectives of SME development in Russia and identification of critical issues hampering it.
\end{abstract}

Keywords: Small and Medium-Sized Businesses (SMB), Region, State Support, Efficiency.

\section{Introduction}

Nowadays small and medium-sized businesses (SMB) are considered by researchers and politicians as a basement of socio-economic development of the state and its particular regions. SMB generate new jobs, facilitate to reduce unemployment in a region, make a considerable contribution to the regional budget by means of tax payments, attract investment to regional economics, etc. Therefore, many studies are dedicated to the impact of small and mediumsized entrepreneurship (SME) to economics of a territory $[1,2$, etc.].

However, the issue of the impact of current socioeconomic situation to the development and successful operation of small and medium-sized entities is not less relevant or important $[3,4,5$, etc.]. Since SMB can potentially improve socio-economic situation in a region, public sector is focused on creating enabling environment for those entities and providing assistance to them. The most common support measures for small and medium-sized entrepreneurship are subsidies from regional budgets $[6,7,8,9,10,11]$, government lending programmes [12], tax exemptions and simplified taxation [13] and other preferences and benefits for such companies $[14,15,16]$. Yet not even the examination of these support measures is the most essential issue. Primarily, academics pay special attention to the efficiency of the measures carried out. This article thereby deals with state support measures for SME in particular regions. The main objectives of the study are to analyse these measures as well as estimate their efficiency and prospects for Russian regions. Three subjects of the Russian Federation located in different geographic and administrative districts were selected as the study objects: Republic of Tatarstan, Amur Oblast, and Kamchatka Krai. The study outcome is expected to represent a comparison between these regions in the performance level of public support measures for SME, along with identification of key problems and prospects of regional public policy development in this area.

\section{Research Methods}

The work is built upon such scientific methods as analysis of statistical data and regulations along with comparison and ranking the research objects by selected indicators.

The research was conducted in several stages. At the first stage regulatory documents and regional development programmes were examined. On the basis of this documentation we defined key activities and areas of public support for small and mediumsized businesses in the regions reviewed. The work continued with ranging the subjects of Russia according to the level of development and diversity of regional SME supporting policies. The rating was compiled as follows: each region was assigned with a rating value depending on the availability of such a support: 1 - if present, 0 - if absent. The final rank of the region $(\mathrm{R})$ was calculated by the following formula:

$$
\mathrm{R}=\sum_{\mathrm{i}=1}^{\mathrm{n}} \mathrm{r}_{\mathrm{i}}
$$

Where $r_{i}-$ a rating value for a specific area of support, $\mathrm{n}-\mathrm{a}$ sequence number of the area of SMB support. 
The second stage of the research was aimed to define the efficiency level of the considered support measures for small and medium-sized businesses. At this stage we analyzed the statistical data reflecting the SMB development level in selected territorial subjects of Russia. Following that, a rating of regions was compiled. When ranging, a region with the highest rate was assigned with value 2 , then value 1 in descending order, and 0 was assigned to a region with the lowest rate. Final cumulative rate was defined, by analogy, as a sum of particular values. The results of the two ratings of regions (1) for the variety of SMB support measures implemented, and 2) by the level of SMB development) were compared to assess the effectiveness of the public support measures for SME. The comparison resulted in several conclusions about feasibility of the support measures carried out, crucial issues and enhancement prospects of state policy on supporting SME.

Table 1.Rating of Regions for the Variety of SMB Support Measures Implemented

\begin{tabular}{|c|c|c|c|c|}
\hline № & Area of Support & $\begin{array}{l}\vec{y} \\
\frac{\pi}{0} \\
0 \\
0 \\
\vdots \\
\vdots \\
\vdots\end{array}$ & 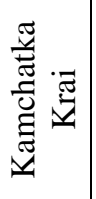 & 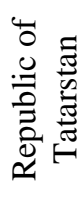 \\
\hline 1. & Advisory Support of Small and Medium-Sized Business Entities & 1 & 1 & 0 \\
\hline 2. & $\begin{array}{l}\text { Implementation of educational programmes for small and medium-sized } \\
\text { enterprises, advanced trainings for small and medium-sized enterprises, single } \\
\text { events, internships and workshops }\end{array}$ & 0 & 1 & 0 \\
\hline 3. & Development of microfinance system & 0 & 1 & 1 \\
\hline 4. & Investment loans provided to small and medium-sized enterprises & 0 & 1 & 1 \\
\hline 5. & $\begin{array}{l}\text { Subsidies to small and medium-sized enterprises in order to partly reimburse } \\
\text { expenses related to first instalment (advance payment) upon concluding a } \\
\text { leasing agreement }\end{array}$ & 1 & 1 & 1 \\
\hline 6. & $\begin{array}{l}\text { Subsidies to small and medium-sized enterprises in order to partly reimburse } \\
\text { expenses related to purchase of equipment which is necessary for creation and } \\
\text { (or) enhancement or modernization of goods (activities, services) production }\end{array}$ & 1 & 1 & 1 \\
\hline 7. & $\begin{array}{l}\text { Subsidies to small and medium-sized enterprises in order to partly reimburse } \\
\text { expenses related to the creation and (or) improvement day-care groups for pre- } \\
\text { school children }\end{array}$ & 1 & 1 & 0 \\
\hline 8. & $\begin{array}{l}\text { Subsidies to local commodity producers (small and medium-sized enterprises) } \\
\text { in order to partly reimburse expenses related to the creation of retail networks } \\
\text { aimed at the distribution of self-produced goods }\end{array}$ & 1 & 1 & 0 \\
\hline 9. & Grants to small enterprises for creation of small innovative companies & 0 & 1 & 1 \\
\hline 10. & $\begin{array}{l}\text { Grants to business start-ups (subjects of small entrepreneurship) for } \\
\text { establisment of their own enterpises }\end{array}$ & 0 & 1 & 0 \\
\hline 11. & $\begin{array}{l}\text { Support for the municipal programs of small and medium-sized } \\
\text { entrepreneurhip development }\end{array}$ & 0 & 1 & 1 \\
\hline 12. & $\begin{array}{l}\text { Provision of guarantees (safeguards) on obligations (credit, loan and leasing } \\
\text { agreements) of small and medium-sized enterprises and organisations which } \\
\text { form the support infrastructure for small and medium-sized enterprises }\end{array}$ & 0 & 1 & 1 \\
\hline
\end{tabular}

Knowledge base of the study was represented by regulatory legal acts and statistics published on official websites of federal and regional authorities.

\section{Results}

In each region under review there is a programme for the comprehensive socio-economic development of the territory, and also programmes or subprogrammes on SME support. These programmes or sub-programmes might be classified upon various grounds: authorities responsible for their implementation; sectors of the economy; types of supporting activities (subsidy, concessional lending, entrepreneur trainings, counselling, etc.) The examination of regulatory documents data made it possible to identify 14 key areas of supporting small and medium-sized entities. Moreover, the regions were compared one to another upon presence or absence of such support activities. Based on this comparison, the following rating has been composed (Table 1): 


\begin{tabular}{|c|l|c|c|c|}
\hline 13. & $\begin{array}{l}\text { Deployment of nfrastructure facilities for managing and developing small and } \\
\text { medium-sized enterprises }\end{array}$ & 0 & 1 & 1 \\
\hline 14. & Development of guarantee facilities of SME support & 1 & 0 & 1 \\
\hline & Final rate & 6 & 13 & 9 \\
\hline & Rating position & 3 & 1 & 2 \\
\hline
\end{tabular}

From the Table 1 one can see that none of the considered regions implement the full list of possible support measures. The most diverse range of activities focused on supporting small and mediumsized entities is undertaken on the territory of Kamchatka Krai. The outsider of this rating is Amur Oblast. In this region only subsidization to SMB is being realized. At the same time all the activities associated with informing businessmen as well as the measures of providing financial benefits are neglected. However, it might be noted that subsidization of SMB is not always the most efficient measure, since financial assistance is provided to beneficiaries (businessmen) on nonrefundable terms without any obligation from their side. The measures such as microfinancing or provision of state guarantees require greater level of responsibility from entrepreneurs' side, because of the obligation to refund the financial resources provided, that is why these measures might be more effective.

The Republic of Tatarstan falls between two other regions in the rating. Diverse measures of financial support are well-developed in this area. However, there are few activities associated with education and awareness of citizens. Lack of information about potential opportunities for small and medium-sized entrepreneurs restricts the number of public support recipients. This may also reduce the efficiency of the whole scope of state support policy for SMB.

It was decided to analyze statistical data which reflect the level of small and medium-sized business development in the regions in order to evaluate the efficiency of the public support measures being implemented. To do so, 10 statistical indicators were selected, then examined, and became the basis for another rating of regions. Statistical data are represented in the Table 2 .

Table 2.Development Level of SMB in Regions of The Russian Federation

\begin{tabular}{|l|l|l|l|l|}
\hline № & SMB Development Index & Amur Oblast & Kamchatka Krai & $\begin{array}{l}\text { Republic of } \\
\text { Tatarstan }\end{array}$ \\
\hline 1 & $\begin{array}{l}\text { Total amount of enterprises (at the beginning } \\
\text { of 2017), ea. }\end{array}$ & 26346 & 14847 & 148131 \\
\hline 2 & Average SMB number growth rate (\%) & 15 & 0,1 & 31,1 \\
\hline 3 & $\begin{array}{l}\text { Average number of listed employees (at the } \\
\text { beginning of 2016), thousand pers. }\end{array}$ & 47,4 & 2,1 & 330,4 \\
\hline 4 & Average enterprise staff headcount, pers. & 1,8 & 72637 & 2,2 \\
\hline 5 & Turnover of all enterprises, million rub. & 75338 & 4,89 & 707300 \\
\hline 6 & Average enterprise turnover, million rub. & 2,85 & 21124,9 & 4,77 \\
\hline 7 & $\begin{array}{l}\text { Funds allocated for SMB support (budget), } \\
\text { thousand rub. }\end{array}$ & 9448,6 & 13291,6 & 136580,9 \\
\hline 8 & $\begin{array}{l}\text { Funds provided for SMB support (actual), } \\
\text { thousand rub }\end{array}$ & 206,5 & $-7833,3(-63)$ & $-488354,4$ \\
\hline 9 & $\begin{array}{l}\text { Discrepancy between actual and allocated } \\
\text { expenses for SMB support, thousand rub. }(\% \\
\text { of allocated funds) }\end{array}$ & $-9242,1(-98 \%)$ & & $(-78 \%)$ \\
\hline 10 & Number of contracts concluded with SMB, ea. & 733 & 493 & 825 \\
\hline
\end{tabular}

Based on the statistical data presented in the Table 3, it might be stated that the regions differ significantly in the entrepreneurship level. We can also note that SMB has been developing in all the regions. However, even if the growth rate of small and medium-sized companies in Tatarstan and Amur Oblast quite high (18\% \& $15 \%$ respectively), their number in Kamchatka Krai barely changes. Also, it is worth considering budget indicators of SMB support. Initially, rather significant amounts of funds are allocated in regional budgets. In fact, just a small proportion is used. This point reflects inefficiency of budget expenditures for SMB support, as well as lack of interest shown by entrepreneurs who potentially are recipients of this funding. It is worth noting individually about relative 
indices of SMB development. Despite the fact that Tatarstan considerably outpaces the other regions under the study in terms of the amount of SMB and gross turnover, the average turnover of an entity here is lower than in Kamchatka Krai.
According to the data reported we compiled a rating of Russian regions by the level of SMB development. Its results are reflected in the Table 3.

Table 3.Rating of Russian Regions by the Level of SMB Development

\begin{tabular}{|l|l|l|l|}
\hline № & Region of Russia & Ranking value & Rating position \\
\hline 1 & Amur Oblast & 5 & 3 \\
\hline 2 & Kamchatka Krai & 7 & 2 \\
\hline 3 & Republic of Tatarstan & 18 & 1 \\
\hline
\end{tabular}

From the Table 3 it is clear that Tatarstan is a leader by the level of SMB development. The underdog is Amur Oblast. The comparison of the rating of SMB supporting policy development level with the SMB development rating prompts the following conclusion. Amur Oblast is the outsider in two ratings. It means that public support measures are sorely lacking, and this directly affects the SMB development in the region. The rating results of the other territories reviewed vary greatly. For instance, Kamchatka Krai became the leader of the first rating. In the second one it placed second. It reflects low efficiency of state support policy for SMB in this region. The number of activities carried out here is rather considerable. However, those measure do not make proper impact in the form of increased economic activity. The opposite is the case of Tatarstan. Not all the measures are provided there, but SMB is developed enough. On the one hand, it is good for for socio-economic development of this subject of the Russian Federation. At the same time we can also notice inefficiency of public support for SMB from the same figures. Small and mediumsized entrepreneurship in Tatarstan have been developing independently. This allows us to state that there is no urgent need in public measures to support SMB, on which a significant amount of budgeting is allocated.

\section{Conclusion}

On the basis of the analysis the following conclusions can be made. None of public policies on SMB support in the regions reviewed can be described as effective. The study let us identify two groups of reasons. The first one consists of administrative reasons. These might include limited number of areas of state support for SMB, similar measures of support, low incentives to use allocated funds efficiently by entrepreneurs (beneficiaries) when providing particular types of SMB support, non-compliance of the measures implemented with the demands of entrepreneurs and socio-economic situation in region, etc.

However, based on the study it may also be concluded that implemented measures do not always lead to direct positive impact. In this regard, it is necessary to pinpoint the second group of reasons of public policy inefficiency on SMB support. These are socio-economic, ecological, geographic and other objective reasons. The article covers 3 regions located in different geographical territories. Geographical, climatic, demographic, transport, social and other conditions in the Republic of Tatarstan are significantly better in many aspects than such conditions in Kamchatka Krai or Amur Oblast. This affects the level of SMB development in these regions. Moreover, public support for SMB in any of them is not focused on improving the environment, and hence does not lead to proper outcomes.

To sum up, we might conclude that not only direct assistance to entrepreneurs should be provided, but also operational environment for business must be enhanced in different regions to comprehensively improve and achieve higher efficiency of the state policy on supporting SMB.

\section{Acknowledgements}

The work is performed according to the Russian Government Program of Competitive Growth of Kazan Federal University.

\section{References}

1. Balogun, O.A., Ansary, N. Determinants of business overdraft accessibility within small and medium-sized enterprises in the South African construction industry: A case of gauteng province. Advances in Intelligent Systems and Computing, Volume 594, 2018, Pages 229-240.

2. Memili, E., Fang, H., Chrisman, J.J., De Massis, A. The impact of small- and medium-sized family firms on economic growth. Small Business Economics, Volume 45, Issue 4, $23 \overline{\text { July 2015, Pages }}$ 771-785.

3. Massón-Guerra, J.L., Ortín-Ángel, P. Regional entrepreneurship capital and firm production. Small Business Economics, Volume 49, Issue 3, 5 April 2017, Pages 595-607

4. Gherhes, C., Vorley, T., Williams, N. Entrepreneurship and local economic resilience: the impact of institutional hysteresis in peripheral 
places. Small Business Economics, 6 October 2017, Pages 1-14.

5. Giudici, G., Guerini, M., Rossi-Lamastra, C. The creation of cleantech startups at the local level: the role of knowledge availability and environmental awareness. Small Business Economics, 3 October 2017, Pages 1-16.

6. Cin, B.C., Kim, Y.J., Vonortas, N.S. The impact of public R\&D subsidy on small firm productivity: evidence from Korean SMEs. Small Business Economics, Volume 48, Issue 2, 1 February 2017, Pages 345-360.

7. Czarnitzki, D., Bento, C.L. Evaluation of public R \& D policies: A cross-country comparison. World Review of Science, Technology and Sustainable Development, Volume 9, Issue 2-4, July 2012, Pages 254-282.

8. Cerqua, A., Pellegrini, G. Industrial policy evaluation in the presence of spillovers. Small Business Economics, Volume 49, Issue 3, 12 April 2017, Pages 671-686.

9. Cin, B.C., Kim, Y.J., Vonortas, N.S. The impact of public R\&D subsidy on small firm productivity: evidence from Korean SMEs. Small Business Economics, Volume 48, Issue 2, 1 February 2017, Pages 345-360.

10. Czarnitzki, D., Delanote, J. R\&D policies for young SMEs: input and output effects. Small Business Economics, Volume 45, Issue 3, 24 October 2015, Pages 465-485.

11. Mateut, S. Subsidies, financial constraints and firm innovative activities in emerging economies. Small Business Economics, 16 June 2017, Pages 132

12. Ughetto, E., Scellato, G., Cowling, M. Cost of capital and public loan guarantees to small firms. Small Business Economics, Volume 49, Issue 2, 1 August 2017, Pages 319-337.

13. Matus, A., Guerra, E., Fuertes, W., Gómez, M., Aules, H., Villacís, C., Toulkeridis, T. On the development of an electronic invoicing solution to integrate SMEs with a tax-collection egovernmentplatform. 2017 4th International Conference on eDemocracy and eGovernment, ICEDEG 2017, 29 June 2017, Pages 94-101.

14. Lewis, G.H. Effects of federal socioeconomic contracting preferences. Small Business Economics, 4 May 2017, Pages 1-21.

15. Martí, J., Quas, A. A beacon in the night: government certification of SMEs towards banks. Small Business Economics, 1 February 2017, Pages 1-17.

16. Butler, I., Galassi, G., Ruffo, H. Public funding for startups in Argentina: an impact evaluation. Small Business Economics, Volume 46, Issue 2, 1 February 2016, Pages 295-309. 